\title{
Modelling the Effects of Affordable Housing 'Sticks' and 'Carrots' for Developer-Delivered Projects
}

\author{
Georgia Warren-Myers, Erryn McRae, Katrina Raynor, Matthew Palm \\ ${ }^{I}$ Melbourne School of Design, University of Melbourne. \\ ${ }^{2}$ University of Toronto
}

Dr Georgia Warren-Myers g.warrenmyers@unimelb.edu.au

Dr Georgia Warren-Myers is a Senior Lecturer in Property at the University of Melbourne and is also a Certified Practising Valuer who has worked in development and valuation and pursues research in housing, affordable housing, sustainability, valuation and development.

Erryn McRae is a student in the Master of Property at the University of Melbourne. Her studies have created an interest in development feasibility and for finding viable solutions to increase the quantum of affordable housing in Melbourne, Australia.

Dr Katrina Raynor is a Research Fellow at the University of Melbourne with expertise in affordable housing, high density housing and urban consolidation. She has a passion for research-policy translation and action research.

Dr Matthew Palm is a postdoctoral researcher at the University of Toronto with expertise in the integration state and federal affordable housing policies, sustainable transportation and land use goals, and analysis of development issues for affordable housing.

\section{Acknowledgements:}

The authors would like to acknowledge the Transforming Housing Research Network for generously supporting this research. Transforming Housing is funded by the Melbourne School of Design, The Lord Mayors Charitable Foundation, Launch Housing and the Brotherhood of St Laurence. In addition, the authors would like to acknowledge the assistance provided by industry developers, consultants and professionals who assisted in providing costing advice and industry perspectives, and the team at Estate Master who provided modelling software and feedback on the analysis. 


\section{Modelling the Effects of Affordable Housing 'Sticks' and 'Carrots' for Developer-Delivered Projects}

The literature suggests both 'Stick' and 'Carrot' initiatives can encourage property developers to include Affordable Housing in their developments. Such initiatives include affordable housing contributions or requirements (the stick) and land cost subsidies, density bonuses, access to low-interest finance, reduced planning timeframes and reduced car parking requirements (the carrots). Despite their widespread application internationally, Australian developers and policymakers have resisted affordable housing incentive structures. Recent legislation in Victoria empowers local planners to approve affordable housing contributions and incentives on a case-by-case basis. This paper provides a quantitative study investigating the feasibility of introducing housing affordability contributions and incentives when developers enter the planning process. This paper endeavours to demonstrate a one-size fits all approach to affordable housing contributions and incentives may not be appropriate illustrated through three case-study projects in Melbourne, Australia. Scenario analysis of three different sized case studies, modelled the effects of affordable housing contributions and incentives on several different feasibility measures. We found optimum scenarios and balance of carrots and sticks. However, project characteristics determined the applicability and effectiveness of an incentive for a project. Thus, planners working in the Victorian legislative environment should consider that a singular approach may not be appropriate for all projects in a municipality or state; and a layered and flexible approach for 'Sticks' and 'Carrots' should be considered to maximise the social benefit of these incentives and ensure developers financial viability.

Keywords: Development feasibility; affordable housing contributions; affordable housing; incentives; affordable housing policy; density bonuses 


\section{Introduction}

Housing affordability and access to affordable housing are critical issues in many cities and regions globally (Wetzstein, 2017). In Australia, dwelling prices have grown rapidly since the 1980s, fuelled by financial deregulation and an iron ore and natural gas resource boom (Yates and Yanotti, 2016). Over this time, the proportion of social housing has decreased from $8 \%$ of all housing stock in 1966 (Hayward, 1996) to 4.3\% in 2016 (Productivity Commission, 2017). This decrease forms part of an international shift, often associated with neoliberalism, from government provided public housing to affordable housing produced through partnerships between governments, not-for-profit and private organisations (Beer, Kearins, Pieters, 2007; Kleit and Page, 2015). Increasingly, political discourse has focused on the inefficiency of statedelivered and managed housing (Dodson, 2006), policy conflict arising from multiple levels of government with differing political interests (Murphy, 2016), fiscal austerity (Rolnik, 2013), and the need for innovation in targeted housing delivery (Bouchard, 2012). Policymakers use this discourse to justify the devolution of responsibility from governments to the private sector (i.e., to governments working in partnership with not-for-profit providers creating philanthropic affordable and social housing). Several mechanisms have emerged to encourage private developers to deliver affordable housing. These mechanisms have been described as 'Carrots' and 'Sticks' and are used by governments to 'soften transitions from state provision of public and social services towards marketisation' (Gurran and Ruming, 2015). Initiatives include regulations (for example, Inclusionary Zoning) operating as either mandatory policies requiring developers to provide a proportion of affordable units within market rate residential developments. They also encompass voluntary initiatives where developers receive incentives for including affordable housing in developments that are sold or tenanted at prices or rents that are affordable to a target income group (Schuetz, Meltzer and Been, 2010). Incentives to increase affordable housing in private developments include: density bonuses, access to discounted finance, the removal of regulatory and planning obstacles and access to subsidised government land. These strategies have gained significant traction in North America (Biggar, 2017; Thaden and Wang, 2017).

Australia has a chequered history of applying planning regulations or incentives to achieve affordable housing (Austin, Gurran and Whitehead, 2014). Reasons for policy transfer failure include the lack of enforceable height restrictions, which precludes the use of density bonuses (Breen, 2014), an absence of enforcement mechanisms (Anderson-Oliver, 2014), the a lack of capacity, financial acumen, willingness and power among local governments to negotiate 
affordable housing outcomes and the use of developer lobbying powers to militate against affordable housing provisions (Beer, 2006). South Australia has mandatory mechanisms in place, and New South Wales has adopted a voluntary approach. Both of these approaches embed affordability requirements through the process of rezoning. This approach seeks to remove the perception of affordable contributions as a development cost (Gurran et al., 2018). However, real estate markets don't necessarily work in such ways, as eventually statutory costs or costs of development imposed in planning are integrated into land sale prices (Davis Langdon, 2009; Property Council of Australia 2009). Voluntary arrangements that depend on negotiations at a stage after the purchase of land leads to greater uncertainty; with higher uncertainty changes to 'option contracts' between developers and landowners would be used in an attempt to offset this, so as to finalise contributions prior to the purchase of land and commitment to the project.

The Victorian Government, in July 2018 made changes to the Planning and Environment Act 1987 that empowered council planners to negotiate with developers during the planning process. The negotiations scheme enables developers to provide affordable housing contributions in return for incentives provided by councils. Although, some of this activity had been occurring in Victoria, the changes mean that decisions are now supported by State legislation and can withstand legal reproach. Policymakers now face a challenge in ensuring that financial illiteracy among government staff, particularly regarding the balance of affordable housing contributions and incentives, does not inhibit the process from delivering affordable units. Both in Victoria and more broadly, there is desire to identify standardised measures of contributions and incentives to be applied to developments, how this works and the implications for development feasibility is unknown and uncertain.

This paper uses a case study approach to bring empirical clarity to this debate. The analysis identifies the relative effectiveness of a milieu of incentives offered in the Victorian context and, in doing so, assists in clarifying that a one-size fits all approach to contributions and incentives is not a viable path to affordable housing production through market-based processes. The study examines three sites in Brunswick, Melbourne, an area where state and local government have resisted generating affordable housing through planning concessions. Brunswick is a well-located, rapidly gentrifying suburb. Each case study enables examination of the financial effects of affordable housing contributions and incentives on different sized sites, from micro to medium sizes. The study has three aims: 1) to examine the effects of affordable housing contributions and incentives on the financial feasibility of developments in 
localities historically allergic to such interventions; 2) to highlight how the different attributes of developments influence the effectiveness of incentives in offsetting the cost of affordable housing contributions; and 3) to draw attention to the variability and opportunities that a combination of 'Stick' and 'Carrot' initiatives could provide in the development of more affordable housing.

This paper begins with a brief literature review of Melbourne's regulatory context and then discusses potential 'stick' and 'carrots' options. Next, the study's methodology is outlined, including the key assumptions and use of EstateMaster (2019). An analysis is then undertaken on the implications the 'carrot' and 'stick' initiatives have on projects' Internal Rate of Return (IRR) and Net Development Profit (Profit). Developers consider both these indicators when making 'go-no-go' decision about projects.

The paper then explores the implications of the findings for practical implementation. The quantitative insights gained from this research should be considered in debates about the potential to increase affordable housing in Australian markets. Finally, the paper concludes with a discussion of the key findings and their applicability to the regulatory context of Australia. The highly variable and contingent nature of the effects the regulations and incentives have on development feasibility are discussed. The flexible approach taken by the Victorian government may be beneficial to various stakeholders; however, has developed a different set of challenges for the different parties in negotiating the affordable housing contributions and incentives.

\section{Housing 'Carrots' and 'Sticks': The Australian Context}

In a market-led, voluntary system, one of the primary barriers to affordable housing provision is the financial implications suffered by developers, who perceive that affordable housing provides insufficient development returns. Hutchison and Disberry (2015) emphasise affordable housing developments in the inner city have higher market risks and construction costs that are not offset by the inherently low returns of affordable housing projects, relative to other development opportunities. Consequently, in a market situation, affordable housing investment and development is limited by private developers' reluctance to consider affordable housing as a voluntary contribution.

The lack of concerted affordable housing strategies in Australia has also been attributed to a lack of housing policies across all three levels of government. The Federal government has 
taken a 'hands-off' approach and has predominantly affected the housing market through its immigration policies and by providing tax incentives to homeowners (Tomlinson, 2012). Local governments have limited budgets and capacity. Melbourne's 32 local governments have little power to apply or enforce consistent housing policies (Raynor, 2017).

Despite decades of concerted advocacy by councils and interest groups to implement Inclusionary Zoning (IZ) (i.e SGS Economies and Planning, 2015), Melbourne still has no formal IZ mechanism. Yet globally, IZ has had considerable take up: in the US with over 700 local governments (Thaden and Wang, 2017); in London as part of the Homes for London IZ program (although developers can apply for a subsidy or a reduction in IZ requirements if this is unfeasible) (Greater London Authority, 2017); and Auckland has proposed the Unitary Plan requiring developments within the Rural Urban Boundary with over 15 dwellings or lots, to have 10\% affordable housing (Murphy, 2016). Until 2018, affordable housing was not acknowledged as a legitimate concern in planning legislation in Victoria and there were no formal definitions as to what constitutes affordable housing. Whilst some small pilot projects in Sydney and some programs in South Australia and the Australian Capital Territory, IZ continues to be uncommon in Australia. This is possibly because of the challenges of IZ, such as its potential to increase to the cost of housing for homebuyers, as developers pass on the foregone profit in higher housing prices to non-IZ dwellings (Freeman, 2016). Furthermore, developers must also factor in the additional costs of affordable housing requirements when purchasing land for future development. But it can take time for this process to filter through the market into land prices, resulting in unfeasible developments or increased costs to homebuyers.

In the absence of consistent incentives or regulation schemes, developers in Australia have delivered very little affordable housing or social housing. To address this issue, Victorian policies have increasingly sought to create opportunities to implement development 'Carrots' and 'Sticks' (Victoria State Government, 2017). Victoria's 'Facilitating Affordable Housing Pilot Program,' for example, will pilot the sale of government land to developers at a reduced price on the proviso it will be used in part for the provision of at least 100 dwellings of affordable housing (Victorian Government, 2017).

Different attempts have been made in the Victorian environment, particularly in providing incentives, various measures have been tested. Density bonuses have similarly had ad-hoc applications in Melbourne. Density bonuses (or floor area uplift) provides higher density limits 
than permitted by existing planning conditions, in return for cash payments or delivering public good such as affordable housing (Bigger, 2017). Density bonuses for the developers provide financial benefits and obviate legal challenges (Ryan and Enderie, 2012). Until 2016, Melbourne did not enforce a density limit in its central business district, resulting in extremely high-density developments and a missed opportunity to fund affordable housing contributions through density bonuses (Hodyl, 2015).

Car-parking requirements have rarely been relaxed and often involve long negotiation processes. However, recent developments, such as the Nightingale development in Brunswick, have shown that car parking requirements can be negotiated on a case-by-case basis (Carey, 2017), particularly if located in transit-rich locations (Palm and Niemeier, 2017). The effect of this type of incentive could vary significantly depending on the type of development site and the type of car parking infrastructure that may be needed, for example, underground, at-grade of above ground car parking.

Local governments could offer a wide range of 'carrots' to developers in exchange for affordable housing contributions, including: expediated planning approvals (reducing time taken for planning as this represents considerable costs which are then passed onto housing consumers (Gurran, 2008; Gurran and Ruming, 2015; Kendall and Tulip, 2018); and reduced car parking requirements could provide benefit to the developer in terms of lowering costs required for car parking. Whilst more significant options that would require greater negotiations and arrangement would be the utilisation of government land, which could assist in reducing the costs of well-located land (Rowley, Costello, Higgins and Phibbs, 2014); and low interest finance options could reduce costs and reduce project risk by providing greater certainty and ease of obtaining finance.

In July 2018, the Victorian Government made changes to the Planning and Environment Act 1987 (DEWLP, 2018) that provided planners with a capacity to negotiate 'sticks' (the affordable housing contributions) and 'carrots' (incentives) with developers; in order to increase the supply of affordable housing in Victoria. By taking this more voluntary approach, yet providing state government support for the negotiations, it is hoped that increased affordable housing will be provided as a result of a more flexible approach. However, the new policy relies on the negotiation capacity of the different stakeholders, namely council planners, developers and housing associations, and to a lesser extent other government participants. A lack of financial literacy and understanding of development feasibility, means that these 
stakeholders may be disadvantaged in negotiations that determine the appropriate balance of affordable contributions required of developers and the type of incentives offered in exchange. This is further complicated by the heterogenous world of property and property development; where no two sites or developments are alike; and consequently, the effect of contributions and incentives will have varying implications for development feasibility and viability of the project.

The incentives discussed above provide examples of the 'Carrots' that can be used as incentives to offset the costs of the affordable housing contributions, the 'Stick' for developers in the context of Melbourne. Some 'Carrots' have been tested in the market; however, their ability to offset the costs associated with affordable housing requirements are less known and yet to be quantified, as developers are hesitant to take on the additional project risks associated with negotiations, leading to uncertain requirements, contributions, incentives and consequently financial outcomes. This research intends to examine the benefits and trade-offs of the various levels of affordable housing contributions and incentives through the modelling of three innercity development site case studies.

\section{Research Approach}

As Reed and Sims (2015) observe, development feasibility models are key project appraisal tools for developers. A case-study approach is necessary in this study because market-based development feasibility models that analyse project opportunities and risks must be location specific to reflect industry practices and provide realistic results (Hutchison and Disberry, 2015). Rowley and Phibbs (2012) created high level static feasibility models to demonstrate the potential of initiatives, but without location specificity, their results were general in nature. This research sought to extend this type of analysis by considering development feasibility models for three nearby market projects of varying sizes and applying a selection of incentives and affordable housing contribution levels. This functions as a control for locational variability in evaluating the relative effectiveness of different affordable housing incentives on projects of different sizes.

In related literature, developed mostly in the United Kingdom, consideration of the impacts of affordable housing incentive programs are commonly calculated through a residual land value approach (Crook et al., 2016; Henneberry 2016). This approach examines the feasibility of planning system changes in terms of how they are likely to impact a developer's choice to enter the market, specifying at what level of land prices a developer can deliver profit 
before and after an affordable housing related zoning change takes place (Crook et al., 2016). For understanding the probable outcomes of such policies, this approach works best in policy contexts with mandatory affordable requirements or strict concession schedules that enable developers to calculate project feasibility prior to acquiring land (Rowley \& Crook, 2016) As noted by Whitehead (2016) the effects of contributions are similar to that of a tax, when applied uniformly across a market; would result in the price offered for the land being reduced all else being held equal. The case of Victoria is different, however, because affordable contributions and related incentives can be negotiated on a case by case basis. Furthermore, local planning authorities in Victoria can pitch agreements after developers have acquired land and begun the planning approval process. This study thus seeks to understand how different 'packages' of incentives and affordable housing requirements may impact project feasibility when developers have already acquired land and have entered the planning process. The results will thus assist both planners and developers in these voluntary negotiation processes by clarifying the potential interactions between project attributes and incentive alternatives, helping local planners enter negotiations with realistic expectations of what varies incentives may yield in terms of increased affordable housing supply. The work could lead to further research utilising a residual land value approach that would examine how the formalisation of effective 'packages' incentives and affordable housing requirements could, in turn, impact land prices and developer participation in the market.

The focus of this research is to examine the implications for developer profit utilising a feasibility analysis, which is a "process of undertaking an assessment to identify the opportunities and risks of a property development project and to estimate the projected costs, revenues and profit potential of the project" (Australian Property Institute's Valuation and Property Standards, 2012, p 11.5.1). In a simple context, feasibility analysis is conducted by determining the value of the completed development project, less the total costs associated with development (including land value) and the remainder is the developers profit (Atherton et al. 2008, pg 163; Havard, 2014, pg 17). This provides a static analysis of a feasibility; to incorporate and reflect the time value of money, a discounted cash flow approach is often adopted (Havard, 2014; Australian Property Institute, 2007); and in this case the authors are utilising the propriety software Estate Master (2018), which is commonly adopted by developers in Australia and also utilised by Australian banking institutions in the assessment of development proposals utilising a cash flow approach and reporting of an Internal Rate of Return and the static reporting of profit as noted above. 
This analysis used three different case sites, which were considered to increase the generalisability of findings and make comparisons while controlling for various factors (Yin, 2014). Estate Master (2018) proprietary software was used to generate and maintain primary data in consultation with area practitioners; reference and guidance in the development of the analysis in Estate Master was made by Havard (2014, pg 219) and Peisley (2018). Excel was used to conduct further data analyses. The study's research phases included Site Investigation and Selection, Baseline Model Creation, Scenario Model Creation and Financial Feasibility Analysis and Findings.

To reflect developer decision-making processes and the new regulatory environment in Victoria, a development appraisal model is considered to be a primary approach for decisionmaking. Atherton et al. (2008) note a feasibility development model is considered to be a rational normative approach to decision-making in development; assuming the veracity of the inputs and assumptions used in the modelling process, this analysis will yield the optimum outcomes based on developers' own benchmarks of acceptability (Atherton et al., 2008, pg 165). The research wanted to examine effects on the Developer's bottom line of affordable housing contributions and incentives; not look at a situation where the additional costs of providing the affordable housing would be passed onto the other apartment purchasers. The realities of competition in this market would prohibit this unless contribution were equally required of other projects, which is not the case presently in Victoria (Rowley and Crook, 2016). Developer returns are often varied dependent upon different situations; size of the project; type of organisation, type of development, location among a range of other factors. This analysis assumes a developer would not pursue a project if it is not as feasible as the baseline project in terms of Internal Rate of Return (IRR) and Net Development Profit (NDP [Profit] calculated as the ratio of the profit margin divided by the total development costs). In undertaking the analysis from this approach, the required rate of return needed to be established, whilst Gollard (2010) in examining the United Kingdom context utilised a rate of 15\% and Havard (2007) and Wilkinson and Reed (2009) used 20\%; in the Australian environment $20 \%$ appears to be the rule of thumb. This was also confirmed in focus groups conducted by the authors in 2018 and 2019 in a related project, which sought opinions of developers to determine industry estimates for feasibility requirements, assumptions and inputs for the development of an Affordable Housing Negotiation Calculator (Warren-Myers et al. $2019 \mathrm{a}, 2019 \mathrm{~b}$ ). In this context, it is assumed the developers' required rate of return is $20 \%$; 
effectively meaning the discount rate utilised in the discounted cash flow modelling of Estate Master is $20 \%$.

Therefore, in this context, this research identifies an effective scenario was one that achieved an IRR and Profit that was equal to or greater than the Baseline IRR and Profit of the project that was not subject to affordable housing contributions and incentives. Thus, the analysis is conducted on a basis demonstrating a $0 \%$ or positive percentage change in IRR and Profit. Additionally, the case study projects were compared to identify any similarities and differences in the effectiveness of the 'Sticks' and 'Carrots' across the case study projects. To examine whether key affordable housing contributions or incentives could be utilised in a more consistent approach across projects; in order to create a more systematic approach to negotiations for developers and planners.

The IRR represents the annualised rate of return when the present value of cash inflows and outflows, (Net Present Value) equal zero. The IRR is an indicator of project financial feasibility because it can be compared across projects or business opportunities of different sizes and timeframes. It is also now a more common assessment metric for development evaluation, as found in the focus groups conducted by Warren-Myers et al. (2019). It is calculated by discounting the net project cash flow back to the present time. The discount rate incorporates the expected risk and return premium a developer places on a project. All models used a $20 \%$ target IRR and discount rate.

The NDP referred to as Profit in this study, is a static assessment of Total Revenue less Total Development Costs including interest paid and received. Thus, it does not take into account TVM; however, Profit is included here because it impacts developers' decisions about projects. In any accounting period, developers have profit and revenue targets and Profit represents a project's contribution to overall profit for a financial period.

\section{Overview of Case Study Projects, Baseline Model Assumptions and affordable housing contributions and incentives}

Market baseline models were developed using key inputs and assumptions, based on market research and industry standard practices which were developed through focus groups and enquiries. The process, inputs and results were reviewed by development, surveying and construction industry academics and practitioners to ensure the assumptions and inputs were realistic. Apartment prices were derived from market analyses of comparable properties, 
comprised of both recently sold and apartments for sale in new developments within the location area.

Headline construction costs were based on the number and style of apartments and derived using data from Rawlinsons Construction Cost Consultants and Quantity Surveyors (2017). These calculations and figures were reviewed by a local Quantity Surveyor whose feedback was incorporated into the models. A target IRR of $20 \%$ was adopted to reflect local development practice required rate of return. This rate was used in the Baseline models as the discount rate or required rate of return.

Another factor that was considered and controlled for was the $100 \%$ debt assumption. This is unlikely in the current market; however, an examination of the debt financing structures is beyond the scope of this research. The rationale for assuming a $100 \%$ finance position is to ensure comparability across the projects; as likely different financing structures would likely be used and this would influence the results, thus using a standard function means greater comparability and understanding of the effects of the contributions and incentives on the project itself, not the effect of financing arrangements. The interest rate used in the Baseline models was chosen by researching rates available to local developers of small to medium projects in the current financial climate. However, it should be noted, interest rates and terms vary depending on the financier, size of the project, development firm reputation and the investor's equity stake in the project. Similar to the debt structure, these factors have multiple permutations that are beyond the scope of this research. Consequently, for the purposes of analysis and to ensure comparability across projects, both the debt and interest rate were consistently maintained across the scenarios (i.e., a $100 \%$ debt and a $12 \%$ interest rate). It should be noted, the $100 \%$ debt finance consideration enhanced the feasibility of the lowinterest finance option.

Three case studies were identified in Brunswick, Melbourne; these properties were on the market at the time of the inception of the research and were sold as development sites. Their prices were incorporated into the development feasibility. The three are named and referred to throughout this paper as Micro, Small and Medium, which reflects the comparative size of the developments. Table 1. Provides an outline of the baseline model for each project modelled in the Estate Master program (with the Estate Master outputs included in the Appendix) and the assumptions and scenarios applied are detailed in Table 2. Table 2 provides the list of incentives applied to the different case studies. Detailing what incentive 
was used, what assumptions were applied in that context and key variables affected in the feasibility and by what quantum.

Analysis of the market baseline models showed the Micro project had the most feasible baseline model, with an IRR of $24.38 \%$ and Profit just under \$1 million. Conversely, the Medium project had an IRR of $17.62 \%$ and Profit of $\$ 10.1$ million, whilst the Small project was the least feasible with an IRR of $14.24 \%$ and Profit of $\$ 1.6$ million.

Table 1. Case Study Project—Market Baseline Model Overview.

\begin{tabular}{|c|c|c|c|}
\hline & Micro & Small & Medium \\
\hline \multicolumn{4}{|l|}{ Project particulars } \\
\hline Land Area & $133 \mathrm{sqm}$ & $509 \mathrm{sqm}$ & $2,161 \mathrm{sqm}$ \\
\hline Site & $\begin{array}{l}\text { Rectangular shaped } \\
\text { land parcel }\end{array}$ & $\begin{array}{l}\text { Rectangular, narrow } \\
\text { street frontage }\end{array}$ & $\begin{array}{l}\text { Large site, regular } \\
\text { shaped land parcel }\end{array}$ \\
\hline Levels (height) & 6 & 6 & 6 \\
\hline Product & 5 Apartments & 30 Apartments & 114 Apartments \\
\hline Style & $\begin{array}{l}\text { 3-bedroom } \\
\text { apartments }\end{array}$ & $\begin{array}{l}\text { 2-bedroom } \\
\text { apartments }\end{array}$ & $\begin{array}{l}\text { 2-bedroom } \\
\text { apartments }\end{array}$ \\
\hline Structure & Single building & Single building & Two buildings \\
\hline Shared space & None & $\begin{array}{l}\text { Lounge and roof-top } \\
\text { garden }\end{array}$ & $\begin{array}{c}\text { Lounge and roof-top } \\
\text { garden }\end{array}$ \\
\hline Parking & At-grade & Stacker & Basement \\
\hline Time in Planning & 10 months & 10 months & 10 months \\
\hline $\begin{array}{l}\text { Commercial/community } \\
\text { space }\end{array}$ & N/A & $\begin{array}{l}1 \text { small retail unit on } \\
\text { the ground floor }\end{array}$ & $\begin{array}{c}5 \text { retail units, } \\
\text { pedestrian access to } \\
\text { Sydney Road }\end{array}$ \\
\hline Build Standard & Medium & Medium & Medium \\
\hline Required rate of return & $20 \%$ & $20 \%$ & $20 \%$ \\
\hline Debt to Equity - \% Debt & $100 \%$ & $100 \%$ & $100 \%$ \\
\hline Interest Rate p.a & $12 \%$ & $12 \%$ & $12 \%$ \\
\hline $\begin{array}{l}\text { Average per sqm } \\
\text { Construction Costs }\end{array}$ & $\$ 1,646$ & $\$ 1,657$ & $\$ 1,622$ \\
\hline $\begin{array}{l}\text { Average per sqm } \\
\text { Apartment Sale Prices }\end{array}$ & $\$ 10,300$ & $\$ 8,800$ & $\$ 9,500$ \\
\hline \multicolumn{4}{|c|}{ Project financials for base case (Appendix Estate Master Summary Output) } \\
\hline Project IRR & $24.38 \%$ & $14.24 \%$ & $17.62 \%$ \\
\hline Net Development Profit & $\$ 997,218$ & $\$ 1,675,352$ & $\$ 10,954,239$ \\
\hline Development Margin & $28.82 \%$ & $14.57 \%$ & $24.08 \%$ \\
\hline Total Revenue $^{1}$ & $\$ 4,295,754$ & $\$ 12,695,134$ & $\$ 54,353,260$ \\
\hline Project Costs ${ }^{2}$ & $\$ 3,298,536$ & $\$ 11,019,782$ & $\$ 43,400,021$ \\
\hline - Construction Costs & $\$ 1,796,653$ & $\$ 7,204,237$ & $\$ 26,945,406$ \\
\hline - Land Purchase Costs & $\$ 957,000$ & $\$ 1,951,400$ & $\$ 8,118,000$ \\
\hline - Other Costs & $\$ 544,883$ & $\$ 1,864,145$ & $\$ 8,336,615$ \\
\hline Selling Costs & $\$ 161,612$ & $\$ 479,866$ & $\$ 2,091,195$ \\
\hline Total Development Costs & $\$ 3,460,148$ & $\$ 11,499,648$ & $\$ 45,491,216$ \\
\hline $\begin{array}{l}\text { \% Land Purchase of total } \\
\text { costs }\end{array}$ & $31 \%$ & $19 \%$ & $20 \%$ \\
\hline
\end{tabular}


Table 2. Scenario initiatives

\begin{tabular}{|c|c|c|c|}
\hline Initiative & Feasibility input affected & Revenue & Costs \\
\hline $\begin{array}{l}\text { Affordable } \\
\text { housing } \\
\text { contribution } \\
\text { (AHC) }\end{array}$ & $\begin{array}{l}\text { AHC requirements of 5\%,10\%, } 15 \% 20 \% \text {, } \\
25 \% \text { and } 30 \% \text { of the development. Sales } \\
\text { revenue reduced and cost reduction } 5 \% . \text { Sold } \\
\text { to an affordable housing not-for-profit } \\
\text { provider for } 25 \% \text { less than the market } \\
\text { purchase price. }\end{array}$ & & \\
\hline Land subsidy & $30 \%$ reduction in land costs & & \\
\hline Density bonus & $\begin{array}{l}\text { Increase in apartments } 20 \% \text {, gross realisation } \\
\text { increase, cost increases. }\end{array}$ & & \\
\hline $\begin{array}{l}\text { Low interest } \\
\text { finance }\end{array}$ & Interest rate from $12 \%$ to $7 \%$ (debt $100 \%$ ) & & \\
\hline $\begin{array}{l}\text { Car parking } \\
\text { reduction }\end{array}$ & $\begin{array}{l}\text { Reduced costs - } \$ 45,000 \text { per carpark, reduced } \\
\text { revenue for the car parks. The additional space } \\
\text { gained by not including a car park, was not } \\
\text { reutilised in the building of the apartments }\end{array}$ & & \\
\hline $\begin{array}{l}\text { Fast-track } \\
\text { planning }\end{array}$ & Reduced planning time by half. & & \\
\hline
\end{tabular}

\section{Results}

The authors tested affordable housing contribution (AHC) scenarios in which each project received one of five incentives while being subject to an affordability commitment that ranged from $5 \%$ of units being affordable to $30 \%$ of units being affordable. We include, as a point of comparison, what the effect of AHC would do to profit and IRR were a project already in the development process (see Figure 1). Regardless of the project size, profit eroded at a greater rate than the IRR in a scenario where affordable contributions were added without incentives during planning. This is likely attributable to TVM impacts. 
Figure 1. Affordable Housing Contributions and Percentage Change in IRR and Profit

The introduction of a $20 \%$ density bonus incentive (Figure 2), substantially increased the capacity of the projects to support up to a $25 \%$ AHC in the Micro project and up to $30 \% \mathrm{AH}$ for the Small and Medium projects. Similarly, the land cost subsidy (Figure 3) also had a positive effect for delivering much higher rates of affordable housing, up to $25 \%$. The low-cost finance option (reduced interest rate by 5\%) (Figure 4) was a less effective incentive, although had a uniform effect across all projects and still supported up to 20\% AHC. Notably, the rate of change varied as AHC increased. This incentive may be appropriate for projects of any scale and could be applied on a standardised platform. Note: given the assumptions of $100 \%$ debt financing, it is likely this incentive was slightly overvalued and the actual AHC amount would be less than $20 \%$ and would require complex agreements between philanthropic organisations, financiers and developers. 
Figure 2. 20\% Density Bonus and Percentage Change in IRR and Profit

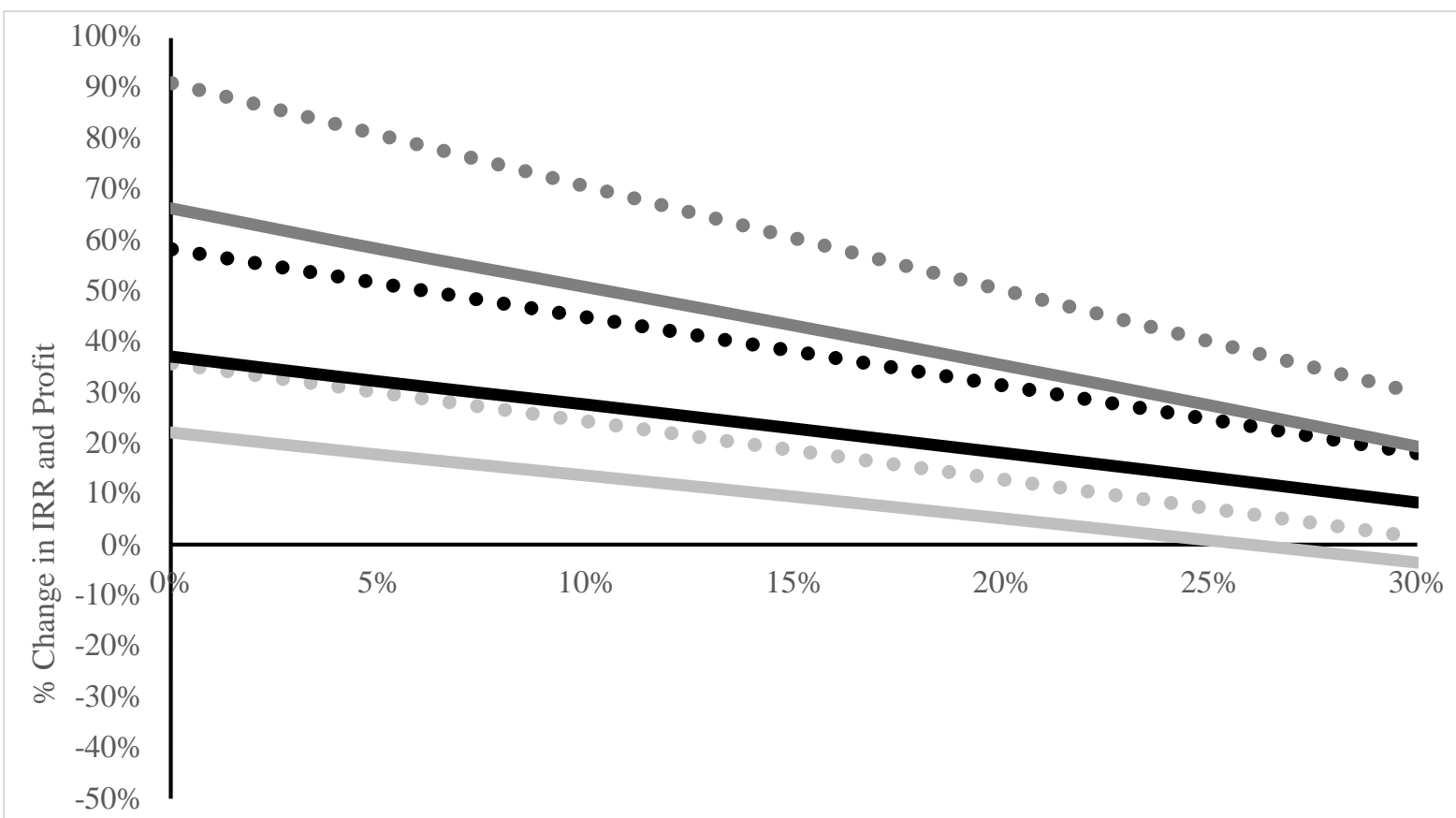

\% Affordable Housing

- Profit - Medium IRR - Medium
Profit - Micro - Profit - Smal

Figure 3. 30\% Land Subsidy and Percentage Change in IRR and Profit

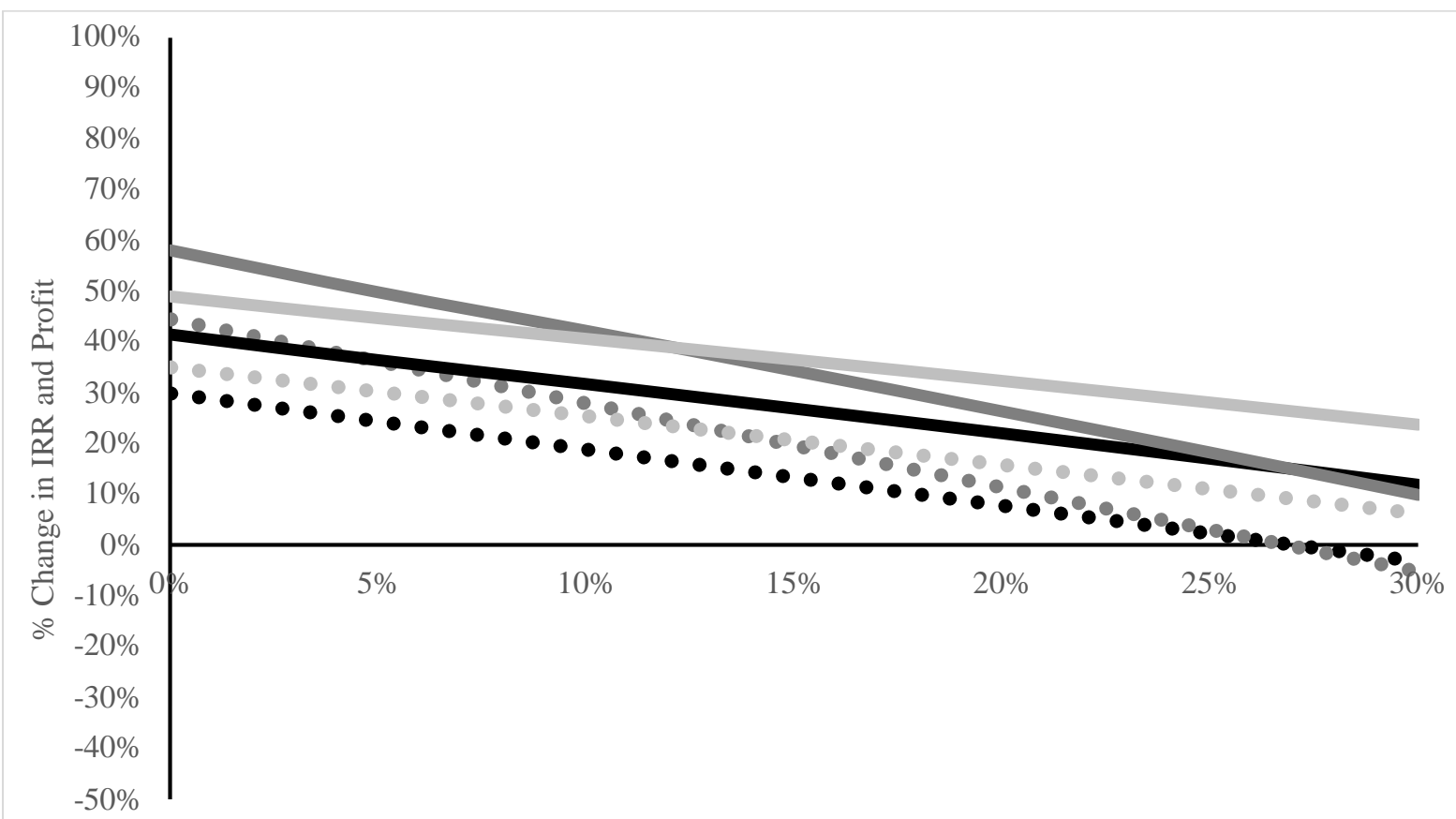

\% Affordable Housing

- - Profit - Medium

@IRR - Medium
- Profit - Small
IRR - Small

- Profit - Micro

IRR - Micro 
Figure 4. Low Interest Finance and Percentage Change in IRR and Profit

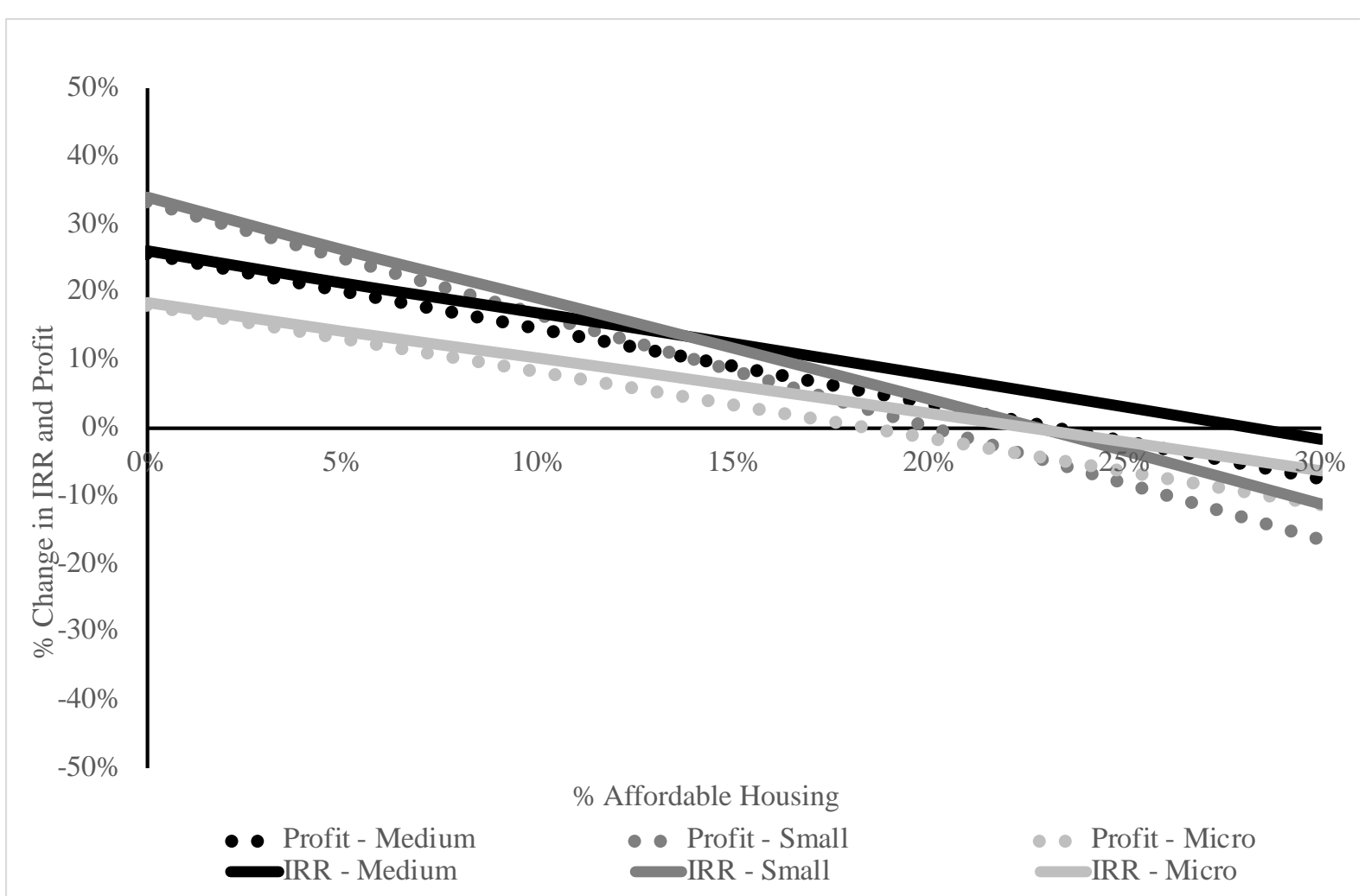

The fast-track planning approval (Figure 5) had a mixed effect, with the IRR's affected more strongly than the profit margins across the board; as a result of TVM impact, bringing all cash flow forward and making the change in IRR significantly higher than the change in Profit. This suggests a benchmark of $10 \%$ AHC would still enable viability across all projects, with potential up to $20 \%$. The least beneficial incentive was the removal of the car parking requirements, with AHC viable between 5 - 10\% for the Micro and Small projects, and 25\% for the Medium project (Figure 6). Reducing the car parking requirements will be less effective in projects with ground-level parking solutions and lower numbers, as construction costs for ground-level car parking represent a lower proportion of project costs than the construction costs for underground car parks or stackers; which was reflected in the different case studies' results. 
Figure 5. Fast Track Planning and Percentage Change in IRR and Profit

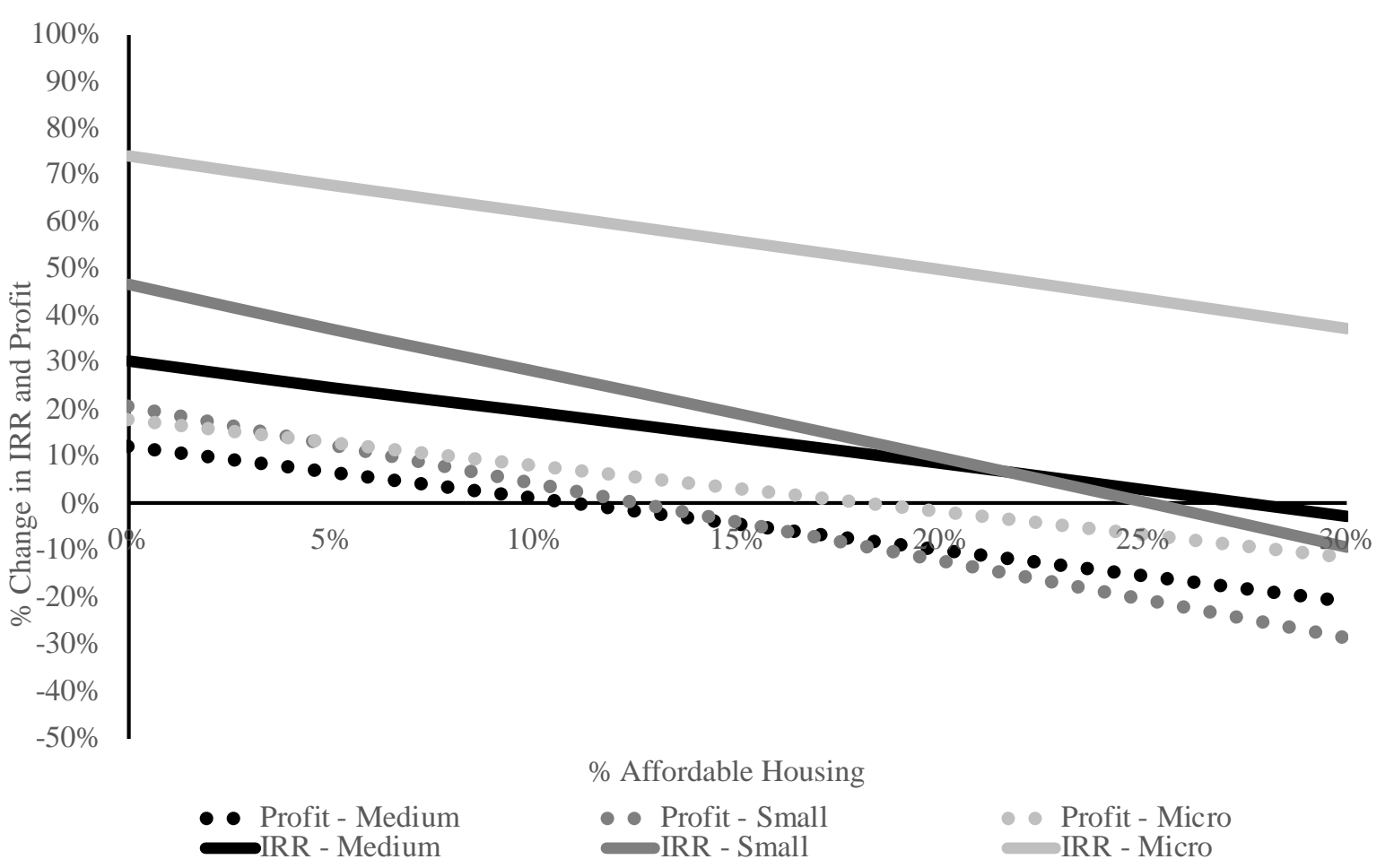

Figure 6. Removal of Car Parking and Percentage Change in IRR and Profit

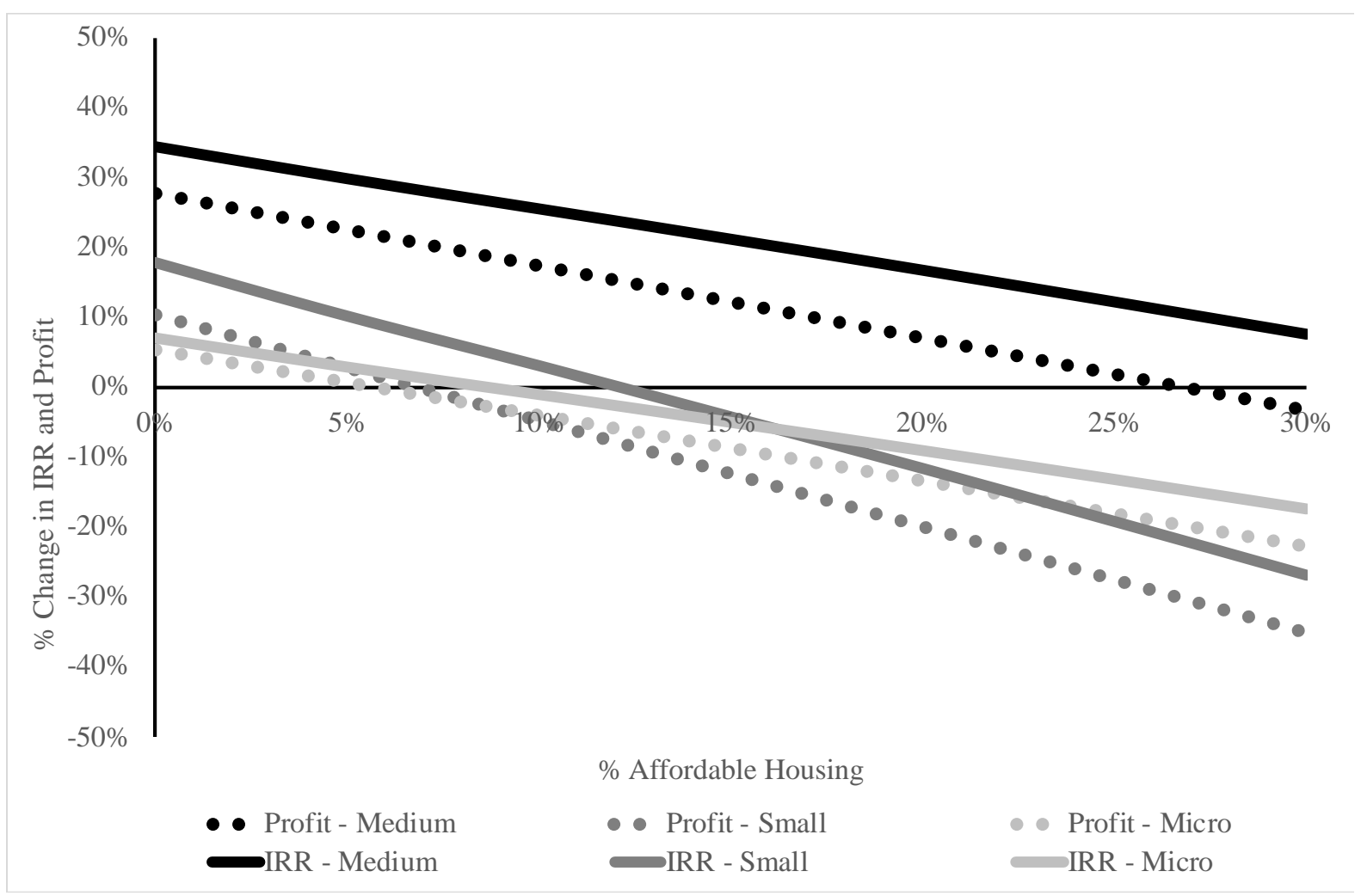




\section{Feasibility scenario analysis comparison to baseline}

The combined effects of $\mathrm{AHC}$ requirements and incentives on project feasibility were also measured as a percentage change for the IRR and profit (see Table 3). The table features white cells that indicate a positive effect on viability above the base case; grey shaded cells indicate equal position with the base case and dark grey indicates below the base case. Dark grey cells represent scenarios a developer is unlikely to agree to, while white cells indicate scenarios a developer is more likely to agree to.

The shading patterns of Table 3 reveal that some incentives may be more effective than others, and that project size mediates the effectiveness of several concessions. A $20 \%$ density bonus maintained or improved project feasibility across all scenarios but one, the exception being the micro project at 30\% affordable units. A 30\% land subsidy, in contrast, preserved or enhanced project feasibility in all scenarios except the small and medium case studies at $30 \%$ affordable units. These differences reflect the relative size of land costs to total costs across the case studies.

Fast track planning offered the least benefit, ensuring project feasibility at $10 \%$ affordable units for the small and medium case studies, and up to $15 \%$ affordable units for the micro project. It should be noted that there is quite a discrepancy between the effects on profit as compared to the IRR for the fast track planning; and this is a result of the time value of money and its compounding effect that this has. The effects of TVM is not seen to affect the results at the same level as the static profit analysis; which indicates the success of the shortened planning period is limited and are commonly not enough to offset the AHC in the static analysis measurement of physical cash profit. This demonstrates the arbitraty nature of the two financial reporting mechanisms and how these can be altered in different ways because of the influence of a $20 \%$ discount rate applied over the time period of the development.

Low finance costs yielded similarly poor outcomes. Finally, the removal of carpark requirements offered the most contrasting results by project size: it reduced project feasibility at all levels of affordable unit contribution in the micro and small projects, but improved feasibility in the medium project at up to a $25 \%$ affordable unit contributions. This difference is likely due to the removal of the high cost of basement parking required only in the medium case study.

From a policy perspective, density bonuses and land subsidization may offer the greatest likelihood of increasing affordable units through voluntary negotiations while preserving 
project feasibility. Carpark waivers can provide similarly beneficial outcomes but only in the context of larger projects wherein the construction costs of carparks are likely to be higher. In contrast, lower financing costs and fast tracking of permitting are much less likely to help councils meet AHC policy goals.

Table 3. Scenario Analysis of the Percentage Change to Market Baseline in Profit and IRR.

\begin{tabular}{|c|c|c|c|c|c|c|c|c|c|c|c|}
\hline \multirow[b]{2}{*}{$\begin{array}{c}\text { Case } \\
\text { Project }\end{array}$} & \multirow[b]{2}{*}{ Initiative } & \multicolumn{2}{|c|}{$\begin{array}{c}10 \% \\
\text { Affordable } \\
\text { units }\end{array}$} & \multicolumn{2}{|c|}{$\begin{array}{c}15 \% \\
\text { Affordable } \\
\text { units }\end{array}$} & \multicolumn{2}{|c|}{$\begin{array}{c}20 \% \\
\text { Affordable } \\
\text { units }\end{array}$} & \multicolumn{2}{|c|}{$\begin{array}{c}25 \% \\
\text { Affordable } \\
\text { units }\end{array}$} & \multicolumn{2}{|c|}{$\begin{array}{c}30 \% \\
\text { Affordable } \\
\text { units } \\
\end{array}$} \\
\hline & & IRR & Profit & IRR & Profit & IRR & Profit & IRR & Profit & IRR & Profit \\
\hline \multirow[t]{5}{*}{ Micro } & $\begin{array}{c}\text { Density } \\
\text { Bonus 20\% }\end{array}$ & $+14 \%$ & $+24 \%$ & $+10 \%$ & $+19 \%$ & $+5 \%$ & $+13 \%$ & $+1 \%$ & $+7 \%$ & $-4 \%$ & $+1 \%$ \\
\hline & $\begin{array}{c}\text { Land } \\
\text { Subsidy } \mathbf{3 0 \%}\end{array}$ & $+41 \%$ & $+26 \%$ & $+37 \%$ & $+21 \%$ & $+32 \%$ & $+16 \%$ & $+28 \%$ & $+11 \%$ & $+24 \%$ & $+6 \%$ \\
\hline & $\begin{array}{c}\text { Low Finance } \\
7 \%\end{array}$ & $+10 \%$ & $+8 \%$ & $+6 \%$ & $+3 \%$ & $+2 \%$ & $-2 \%$ & $-2 \%$ & $-7 \%$ & $-6 \%$ & $-11 \%$ \\
\hline & $\begin{array}{c}\text { Fast Track - } \\
3 \text { months }\end{array}$ & $+62 \%$ & $+8 \%$ & $+56 \%$ & $+3 \%$ & $+50 \%$ & $-2 \%$ & $+44 \%$ & $-6 \%$ & $+37 \%$ & $-11 \%$ \\
\hline & $\begin{array}{c}\text { Remove } \\
\text { Car-parks }\end{array}$ & $-1 \%$ & $-4 \%$ & $-5 \%$ & $-9 \%$ & $-9 \%$ & $-13 \%$ & $-13 \%$ & $-18 \%$ & $-17 \%$ & $-23 \%$ \\
\hline \multirow[t]{5}{*}{ Small } & $\begin{array}{c}\text { Density } \\
\text { Bonus 20\% }\end{array}$ & $+51 \%$ & $+71 \%$ & $+43 \%$ & $+60 \%$ & $+36 \%$ & $+50 \%$ & $+28 \%$ & $+40 \%$ & $+20 \%$ & $+30 \%$ \\
\hline & $\begin{array}{c}\text { Land } \\
\text { Subsidy } 30 \% \\
\end{array}$ & $+42 \%$ & $+28 \%$ & $+34 \%$ & $+20 \%$ & $+26 \%$ & $+12 \%$ & $+18 \%$ & $3 \%$ & $+10 \%$ & $-5 \%$ \\
\hline & $\begin{array}{c}\text { Low Finance } \\
7 \%\end{array}$ & $+19 \%$ & $+17 \%$ & $+12 \%$ & $+8 \%$ & $+4 \%$ & $0 \%$ & $-3 \%$ & $-8 \%$ & $-11 \%$ & $-16 \%$ \\
\hline & $\begin{array}{c}\text { Fast Track - } \\
3 \text { months } \\
\end{array}$ & $+28 \%$ & $+4 \%$ & $+19 \%$ & $-4 \%$ & $+10 \%$ & $-12 \%$ & $0 \%$ & $-20 \%$ & $-9 \%$ & $-29 \%$ \\
\hline & $\begin{array}{c}\text { Remove } \\
\text { Car-parks }\end{array}$ & $+3 \%$ & $-5 \%$ & $-4 \%$ & $-12 \%$ & $-12 \%$ & $-20 \%$ & $-19 \%$ & $-27 \%$ & $-27 \%$ & $-35 \%$ \\
\hline \multirow[t]{8}{*}{ Medium } & $\begin{array}{c}\text { Density } \\
\text { Bonus 20\% }\end{array}$ & $+28 \%$ & $+45 \%$ & $+23 \%$ & $+38 \%$ & $+18 \%$ & $+31 \%$ & $+13 \%$ & $+25 \%$ & $+8 \%$ & $18 \%$ \\
\hline & $\begin{array}{c}\text { Land } \\
\text { Subsidy } \mathbf{3 0 \%} \\
\end{array}$ & $+32 \%$ & $+19 \%$ & $+27 \%$ & $+13 \%$ & $+22 \%$ & $+8 \%$ & $+17 \%$ & $+2 \%$ & $+12 \%$ & $-3 \%$ \\
\hline & $\begin{array}{c}\text { Low Finance } \\
7 \% \\
\end{array}$ & $+17 \%$ & $+15 \%$ & $+12 \%$ & $+9 \%$ & $+8 \%$ & $+4 \%$ & $+3 \%$ & $-2 \%$ & $-2 \%$ & $-7 \%$ \\
\hline & $\begin{array}{c}\text { Fast Track - } \\
3 \text { months }\end{array}$ & $+20 \%$ & $+1 \%$ & $+14 \%$ & $-4 \%$ & $9 \%$ & $-10 \%$ & $+3 \%$ & $-15 \%$ & $-3 \%$ & $-21 \%$ \\
\hline & $\begin{array}{c}\text { Remove } \\
\text { Car-parks } \\
\end{array}$ & $+26 \%$ & $+17 \%$ & $+21 \%$ & $+12 \%$ & $+17 \%$ & $+7 \%$ & $+12 \%$ & $+2 \%$ & $+8 \%$ & $-3 \%$ \\
\hline & \multicolumn{11}{|c|}{$\begin{array}{l}\text { Viable - Both the IRR and Profit are greater than or equal to the Baseline figure, with a positive or } 0 \\
\text { percentage change }\end{array}$} \\
\hline & \multicolumn{11}{|c|}{$\begin{array}{l}\text { Possibly viable - One of the IRR and Profit are greater than or equal to the Baseline figure, with a } \\
\text { positive or } 0 \text { percentage change. }\end{array}$} \\
\hline & \multicolumn{11}{|c|}{$\begin{array}{l}\text { Not Viable }=\text { Both the IRR and Profit are less than the Baseline figure, with a negative percentage } \\
\text { change. }\end{array}$} \\
\hline
\end{tabular}

\section{Discussion and Conclusions}

The results of our study support previous research that has shown, affordable housing contributions (AHC) alone (i.e., in the absence of other incentives for developers) negatively 
affect the feasibility of development projects (Freeman and Schuetz, 2016; Property Council of Australia, 2016). Thus, the implementation of AHC alone will likely deter investors and developers from building in areas or municipalities with AHC requirements unless applied consistently, like in the form of an inclusionary zoning approach, which would then affect the residual land values and, by extension, land prices and developer participation. Completely voluntary and negotiation-based approaches enabled in Victoria, in contrast, mean that contributions and incentives will be individually applied at various stages of the planning process and will depend on a range of factors that will be difficult for councils and developers to predict. This may have further ramifications for councils that expect AHC but lack the skills necessary to determine a fair contribution in exchange for different incentives, due to the high level of uncertainty in the new Victorian process. A failure of councils to pitch reasonable packages of incentives and AHC, however, may discourage developers from considering entering into AHC negotiations at all. Our methodology offers an approach to establishing reasonable negotiating parameters, while providing insights that can guide council planning for negotiations.

Our results offer several principles for Victorian planners to consider before entering into negotiations for AHC. First, the politically easy option of fast-track planning does not offer nearly as many benefits as the more expensive Land Cost Subsidy concession, or the politically difficult Density Bonus. In terms of enhancing project feasibility, our results suggest Density Bonuses and Land Subsidies may offer the highest yields of affordable units while preserving project feasibility. It should be noted, however, that the results do not indicate how these potent initiatives would work in a policy environment in which politically powerful developers are of the view they should be granted density bonuses without providing affordable housing (Breen, 2014; Tomlinson, 2012).

Our results indicate the challenges of encouraging affordable housing contributions in Melbourne, and highlight the necessary incentives that may be required to produce more affordable housing. Although the new legislation provides opportunity for future development and implementation of affordable housing through the negotiation of contributions and incentives; this will rely heavily on the willingness of all parties to engage in the negotiations and have the financial understanding to effectively negotiate outcomes. The introduction of planning concessions for affordable housing is a reflection of political and institutional realities rather than financial constraints. Thus, any notion these approaches (borrowed from North America and Europe) cannot work in the Australian market is incorrect. However, this should 
not be taken as a recommendation for Australian policymakers to implement blanket IZ requirements in exchange for generically pre-defined concessions as occurs in North America and the UK (Thaden and Wang, 2017; Greater London Authority, 2018). Rather, if local planning authorities possessed the tools to conduct analysis such as this paper's, councils could identify interactions between site specific attributes and the benefits derived from various concessions to generate more affordable housing through the planning system. For example, this study found subsidised land supported higher AHC on smaller sites at which land costs constituted a greater share of the total development cost. It also showed larger projects that must comply with high parking requirements by adding expensive underground parking, will benefit most from parking concessions.

By demonstrating the feasibility of affordable housing incentives in a market that has strongly resisted them, we illustrate the potential for such analysis to be the antihistamine to stakeholder allergies regarding these practices. Planning authorities should seek to develop the capacity to conduct similar analyses (or analyses similar to those conducted by Homes for Londoners). Further, to build trust within local communities and ensure mutually beneficial outcomes when negotiating affordable housing contributions and incentives, developers should be required to have a more 'open approach' in what has traditionally been a confidential process. 


\section{Appendix: Estate Master Feasibility Results Summarised for Base Cases}

\begin{tabular}{|c|c|c|c|}
\hline & Micro & Small & Medium \\
\hline \multicolumn{4}{|l|}{ Gross Sales Revenue } \\
\hline Site Area & $133 \mathrm{sqm}$ & 509sqm & $2,161 \mathrm{sqm}$ \\
\hline Gross Floor Area & 665 & 2,443 & 15,000 \\
\hline Project Size & 5 units & 26 units & 114 units \\
\hline Revenue from Apartment Sales & $\$ 4,903,103$ & $\$ 14,492,500$ & $\$ 62,090,000$ \\
\hline Less selling costs & $(\$ 161,612)$ & $(\$ 479,866)$ & $(\$ 2,091,195)$ \\
\hline NET SALES REVENUE & $\$ 4,741,491$ & $\$ 14,012,634$ & $\$ 59,998,805$ \\
\hline TOTAL REVENUE (before GST paid) & $\$ 4,741,491$ & $\$ 14,012,634$ & $\$ 59,998,805$ \\
\hline Less GST paid on all Revenue & $(\$ 445,737)$ & $(\$ 1,317,500)$ & $(\$ 5,644,545)$ \\
\hline TOTAL REVENUE (after GST paid) & $\$ 4,295,754$ & $\$ 12,695,134$ & $\$ 54,354,260$ \\
\hline \multicolumn{4}{|l|}{ Costs } \\
\hline Land Purchase Cost & $\$ 957,000$ & $\$ 1,951,400$ & $\$ 8,118,000$ \\
\hline Land Acquisition Costs & $\$ 62,060$ & $\$ 126,841$ & $\$ 527,670$ \\
\hline $\begin{array}{l}\text { Construction costs } \\
\text { (Residential, Commercial \& General) }\end{array}$ & $\$ 1,796,653$ & $\$ 7,204,237$ & $\$ 26,945,406$ \\
\hline Professional Fees & $\$ 149,472$ & $\$ 599,551$ & $\$ 2,238,281$ \\
\hline Statutory Fees & $\$ 6,292$ & $\$ 25,663$ & $\$ 68,340$ \\
\hline Project Contingency (Reserve) & $\$ 97,880$ & $\$ 390,603$ & $\$ 1,461,744$ \\
\hline Land Holding Costs & $\$ 25,000$ & $\$ 145,000$ & $\$ 340,000$ \\
\hline Pre-sale commissions & $\$ 46,864$ & $\$ 149,904$ & $\$ 604,419$ \\
\hline Finance Changes (inc Fees) & $\$ 45,213$ & $\$ 144,000$ & $\$ 588,000$ \\
\hline Interest Expense & $\$ 404,714$ & $\$ 1,263,837$ & $\$ 6,284,235$ \\
\hline TOTAL COSTS (before GST reclaimed) & $\$ 3,591,149$ & $\$ 12,001,036$ & $\$ 47,176,095$ \\
\hline Less GST reclaimed & $(\$ 292,613)$ & $(\$ 981,254)$ & $(\$ 3,776,073)$ \\
\hline TOTAL COSTS (after GST reclaimed) & $\$ 3,298,536$ & $\$ 11,019,782$ & $\$ 43,400,021$ \\
\hline \multicolumn{4}{|l|}{ Performance Indicators } \\
\hline Net Development Profit ${ }^{1}$ & $\$ 997,218$ & $\$ 1,675,352$ & $\$ 10,954,239$ \\
\hline Development Margin $^{2}$ & $28.82 \%$ & $14.57 \%$ & $24.08 \%$ \\
\hline Net Present Value (discount rate of $20 \%$ p.a.) ${ }^{3}$ & $\$ 121,419$ & $(\$ 434,267)$ & $\$ 46,483$ \\
\hline Benefit Cost Ratio $^{4}$ & 1.0506 & 0.9414 & 1.0016 \\
\hline Project Internal Rate of Return (IRR) $)^{5}$ & $24.38 \%$ & $14.24 \%$ & $\$ 7,419,146$ \\
\hline
\end{tabular}

\section{(After: Estate Master 2019)}

\footnotetext{
${ }^{1}$ Development profit: is total revenue less total cost including interest paid and received (Estate Master 2019)

${ }^{2}$ Development Margin: is profit divided by total costs (including selling costs) (Estate Master 2019)

${ }^{3}$ Net Present Value: is the project's cash flow stream discounted to present value. It includes all financing costs and interest but excludes corporate tax. (Estate Master 2019)

${ }^{4}$ Benefit cost ratio: is the ratio of discounted incomes to discounted costs and includes all financings and interest but excludes corporate tax. (Estate Master 2019)

${ }^{5}$ Internal rate of return: is the discount rate where the NPV above equals Zero, and per annum nominal. (Estate Master 2019)
} 


\section{References}

Australian Property Institute. 2012. Valuation and Property Standards. Retrieved from Australian Property Institute: http://anzvps.api.org.au/11-5-anzrpgn.php

Australian Property Institute. (2007) Valuation Principles and Practice. 2nd Ed. Australian Property Institute, Deakin, Canberra.

Anderson-Oliver, M. 2014. Opportunistic, ill-considered and impossibly vague: barriers to inclusionary zoning in Victoria. Architecture, Building and Planning University of Melbourne: Melbourne.

Aurand, A. 2010. "Density Housing Types and Mixed Land Use: Smart Tools for Affordable Housing?" Urban Studies, 47(5): 1015-1036.

Austin, P.M., Gurran, N., and Whitehead, C.M. 2014. "Planning and affordable housing in Australia, New Zealand and England: common culture; different mechanisms." Journal of Housing and the Built Environment, 29(3): 455-472.

Beer, A., Kearins, B., and Pieters, H. 2007. "Housing Affordability and Planning in Australia: The Challenge of Policy Under Neo-liberalism.” Housing Studies, 22(1): 11-24.

Biggar, J. 2017. Between Public Goals and Private Projects: Negotiating Community Benefits for Density from Toronto's Urban Redevelopment. Department of Geography. University of Toronto.

Bouchard, M.J. 2012. "Social innovation, an analytical grid for understanding the social economy: the example of the Québec housing sector." Service Business, 6(1): 47-59.

Bratt, R.G. 2018. "Affordable Rental Housing Development in the US For-Profit Sector: Implications of a Case Study of McCormack Baron Salazar." Housing Policy Debate, 28(4): $1-26$.

Breen, K. 2014. International approaches to facilitating affordable housing outcomes and their application to Victoria, Australia. (Report October). Australia: AV Jennings Churchill Fellowship.

Carey, A. 2016. "Five storeys, zero car parks: VCAT gives green light to contentious building." The Age. Retrieved from https://www.theage.com.au. 
Commonwealth Government, 2017. Fact Sheet 1.2 - National Housing Infrastructure Facility.

Reducing Pressure on Housing Affordability. Retrieved from http://www.budget.gov.au/201718/content/glossies/factsheets/html/HA_12.htm

Dang, Y., Liu, Z., and Zhang, W. 2014. "Land-based interests and the spatial distribution of affordable housing development: The case of Beijing, China". Habitat International 44: 137145.

Davis Langdon. 2009. Infrastructure charges and new house affordability: the cost of development in Australia's growth centres. (Prepared for the Residential Development Council). June 2009. Sydney, Australia. Davis Langdon.

Dodson, J., 2006. "The "Roll" of the State: Government, Neoliberalism and Housing Assistance in Four Advanced Economies." Housing, Theory and Society 23(4): 224-243.

Estate Master. 2019. Estate Master Development Feasibility. Australia: Argus Estate Master.

Freeman, L. and Schuetz, J. 2016. "Producing Affordable Housing in Rising Markets: What Works?" Cityscape, 19(1): 217-236.

Greater London Authority, 2017. What is Homes for Londoners? Retrieved from https://www.london.gov.uk/what-we-do/housing-and-land/homes-londoners/what-homeslondoners.

Gurran, N., Gilbert, C., Gibb, K., van den Nouwelant, R., James, A. and Phibbs, P. 2018. Supporting affordable housing supply: inclusionary planning in new and renewing

Communities. (AHURI Final Report No. 297). Melbourne: Australian Housing and Urban Research Institute Limited, Melbourne, http://www.ahuri.edu.au/research/final-reports/297 , doi: 10.18408/ahuri-7313201.

Gurran, N. and Bramley, G. 2017. "Planning for inclusionary housing in new and renewing communities." In: Gurran, N. and Bramley, G. (Eds) Urban planning and the housing market. London, UK: Palgrave Macmillan, pp. 337-363.

Gurran, N. and Ruming, K. 2015. "Less planning, more development? Housing and urban reform discourses in Australia.” Journal of Economic Policy Reform. 19(3): 1-19.

Gurran, N., Ruming, K., Randolf., B. and Quintal, D. 2008. Planning, government charges, and the costs of land and housing (Positioning Paper). Melbourne: AHURI. 
Hayward, D. 1996. "The reluctant landlords? A history of public housing in Australia." Urban Policy and Research, 14(1): 5.

Havard, T. 2014. Financial Feasibility Studies for Property Development: Theory and Practice. London: Routledge.

Henneberry, J. 2016. “Development viability.” In: Cook, T., Henneberry, J. \& Whitehead, C. (Eds) Planning Gain: Providing Infrastructure and Affordable Housing. Chister, UK: John Wiley \& Sons, pp. 115-139.

Hodyl, L. 2015. To investigate planning policies that deliver positive social outcomes in hyperdense, high-rise residential environments. (Report February 2015), Australia, Winston Churchill Fellowship 2014.

HousingFirst, 2018. Developments 2018. Retrieved from http://housingfirst.org.au/portfolio/developments.

Hutchison, N. and Disberry, A. 2015. "Market forces or institutional factors: what hinders housing development on brownfield land?" Journal of European Real Estate Research 8(3): 285-304.

Kendall, R. and Tulip, P. 2018. The Effect of Zoning on Housing Prices. (Research Discussion Paper March), Canberra, Australia: Reserve Bank of Australia.

Kleit, R.G. and Page, S.B. 2015. "The Changing Role of Public Housing Authorities in the Affordable Housing Delivery System." Housing Studies 30(4): 621-644.

Manville, M. and Shoup, D.C. 2010. Parking requirements as a barrier to housing development: regulation and reform in Los Angeles. UC Berkely: University of California Transportation Center.

Mukhija, V. 2004. "The Contradictions in Enabling Private Developers of Affordable Housing: A Cautionary Case from Ahmedabad, India.” Urban Studies 41(11): 2231-2244.

Murphy, L. 2016. "The politics of land supply and affordable housing: Auckland's Housing Accord and Special Housing Areas." Urban Studies 53(12): 2530-2547.

Palm, M. and Niemeier, D. 2017. "Does Placing Affordable Housing Near Rail Raise Development Costs? Evidence from California's Four Largest Metropolitan Planning Organizations." Housing Policy Debate 28(2): 1-19. 
Productivity Commission. 2017. Housing and Homelessness. (Report on Government Services 2017, Volume G). Canberra, Australia: Productivity Commission.

Property Council of Australia. 2009. Inquiry into the impact of the state government decision to change the Urban Growth Boundary. (Submission to the Outer Suburban/Interface Service and Development Parliamentary Committee October 2009). Melbourne, Australia: Property Council of Australia

Property Council of Australia, 2016. GSC's much needed housing supply targets face 'inclusionary zoning' risk. Retrieved from https://www.propertycouncil.com.au/Web/Content/Media_Release/NSW/2016/GSC_s_much _needed_housing_supply_targets_face_inclusionary_zoning_risk.aspx.

Ram, P. and Needham, B. 2016. "The provision of affordable housing in India: Are commercial developers interested?" Habitat International 55: 100-108.

Rawlinsons, 2017. Construction Cost Consultants and Quantity Surveyors 2017. Rawlinsons Australian construction handbook. 35 ed. Perth, Western Australia: Rawlhouse Publishing.

Raynor, K. 2017. Delivering affordable housing in Melbourne: Actions, opportunities and implementation. (Housing Summit background paper). June. Melbourne: Transforming Housing, Melbourne School of Design Faculty of Architecture, Building and Planning. The University of Melbourne.

Raynor, K., Mayere, S., and Matthews, T. 2017. "Do 'city shapers' really support urban consolidation? The case of Brisbane, Australia." Urban Studies 55(5): 1-20.

Reed, R. and Sims, S. 2015. Property development. Oxon, UK: Routledge.

Rolnik, R. 2013. "Late Neoliberalism: The Financialization of Homeownership and Housing Rights." International Journal of Urban and Regional Research 37(3): 1058-1066.

Rowley, S. and Phibbs, P. 2012. Delivering diverse and affordable housing on infill development sites. (AHURI Final Report No.193). Melbourne Australia: Australian Housing and Urban Research Institute.

Rowley, S., Costello, G., Higgins, D. and Phibbs, P. 2014. The financing of residential development. (AHURI Final Report No.219). Melbourne Australia: Australian Housing and Urban Research Institute. 
Rowley, S. \& Phibbs, P. 2016. “The incidence and value of planning publications.” In: Cook, Affordable Housing. Chichester, UK: John Wiley \& Sons, pp. 115-139.

Ryan, S. and Enderle, B.E. 2012. "Examining spatial patterns in affordable housing: the case of California density bonus implementation." Journal of Housing and the Built Environment 27(4): 413-425.

Schuetz, J. Meltzer, R. and Been, V. 2010. "Silver Bullet or Trojan Horse? The Effects of Inclusionary Zoning on Local Housing Markets in the United States." Urban Studies 48(2): 297-329.

SGS Economics and Planning Pty Ltd. 2015. Revisiting the economics of inclusionary zoning. Report for SGS Economics and Planning, April. Melbourne: SGS Economics and Planning. Sharam, A., Moran, M., Mason, C., Stone, W. and Findlay, S., 2018. Understanding opportunities for social impact investment in the development of affordable housing. (Report for the Australian Housing and Urban Research Institute. February). Melbourne: Australian Housing and Urban Research Institute.

Sheko, A., Martel, A., and Spencer, A. 2015. Policy, Planning and Financing Options for Affordable Housing in Melbourne, (A background report for Transforming Housing). Melbourne: Transforming Housing, Melbourne School of Design Faculty of Architecture, Building and Planning. The University of Melbourne.

Tang, C.P.Y., Oxley, M. and Mekic, D. 2017. "Meeting commercial and social goals: institutional investment in the housing association sector." Housing Studies 32 (4): 411-427. Thaden, E. and Wang, R. 2017. Inclusionary Housing in the United States: Prevalence, Impact, and Practices, (Working Papers). Cambridge, MA: Lincoln Institute of Land Policy.

Tomlinson, R. 2012. "Introduction: a housing lens on Australia's unintended cities." In: Tomlinson, R. (Ed) Australia's Unintended Cities. Melbourne: CSIRO Publishing. Urbis, (2011). Greenfield Cost Impact Assessment. (Report for URBIS). Brisbane: Urbis. Victoria State Government, 2017. Ministerial interventions for permit applications. Permits and applications. Retrieved from https://www.planning.vic.gov.au/planning-permitapplications/ministerial-permits/ministerial-interventions-in-permit-applications. 
Victorian Government, 2017. Homes for Victorians. Retrieved from http://www.premier.vic.gov.au/homes-for-victorians/.

Walter, R., Evans, A. and Atherwood, S. 2016. "Addressing the Affordable Housing Crisis for Vulnerable Renters: Insights from Broward County on an Affordable Housing Acquisition Tool." Housing Policy Debate 26(1): 123-149.

Warren-Myers, Raynor, K., Palm, M. 2019a. An Affordable Housing Negotiation Calculator: identifying feasible opportunities for voluntary agreements, forthcoming at the State of Australian Cities Conference, December 2019.

Warren-Myers, Palm, M., Raynor, K. 2019b. The Affordable Housing Calculator Manual. June 2019. https://msd.unimelb.edu.au/research/projects/current/transforming-housing/affordablehousing-tools/affordable-housing-calculator. Melbourne: Transforming Housing, Melbourne School of Design Faculty of Architecture, Building and Planning. The University of Melbourne.

Wetzstein, S. 2017. "The global urban housing affordability crisis.” Urban Studies 54(14): 3159-3177.

Whitehead, C. (2016) The Economics of Development Value and Planning Gain, in: Crook, T., Henneberry, J., \& Whitehead, C. (Eds) Planning Gain: Providing Infrastructure and Affordable Housing (Chichester: John Wiley \& Sons).

Whitzman, C., Newton, C., Sheko, A. 2015. Transforming Housing - Partnership Options for policy, investments and demonstration projects. (Transforming Housing) Melbourne: Transforming Housing, Melbourne School of Design Faculty of Architecture, Building and Planning. The University of Melbourne.

Yates, J. and Yanotti, M.B. 2016. "Australia's 25 years with a deregulated housing finance system: looking back and looking forward." In: Lunde, J. and Whitehead, C. (eds) Milestones in European housing finance. John Wiley and Sons: West Sussex, UK, pp.37-53.

Yin, R.K. 2014. Case Study Research design and methods. 5th ed. Thousand Oaks, CA: Sage. 
Table 1. Case Study Project-Market Baseline Model Overview.

\begin{tabular}{|c|c|c|c|}
\hline & Micro & Small & Medium \\
\hline \multicolumn{4}{|l|}{ Project particulars } \\
\hline Land Area & $133 \mathrm{sqm}$ & $509 \mathrm{sqm}$ & $2,161 \mathrm{sqm}$ \\
\hline Site & $\begin{array}{l}\text { Rectangular shaped } \\
\text { land parcel }\end{array}$ & $\begin{array}{l}\text { Rectangular, narrow } \\
\text { street frontage }\end{array}$ & $\begin{array}{l}\text { Large site, regular } \\
\text { shaped land parcel }\end{array}$ \\
\hline Levels (height) & 6 & 6 & 6 \\
\hline Product & 5 Apartments & 30 Apartments & 114 Apartments \\
\hline Style & $\begin{array}{l}\text { 3-bedroom } \\
\text { apartments }\end{array}$ & $\begin{array}{l}\text { 2-bedroom } \\
\text { apartments }\end{array}$ & $\begin{array}{l}\text { 2-bedroom } \\
\text { apartments }\end{array}$ \\
\hline Structure & Single building & Single building & Two buildings \\
\hline Shared space & None & $\begin{array}{l}\text { Lounge and roof-top } \\
\text { garden }\end{array}$ & $\begin{array}{l}\text { Lounge and roof-top } \\
\text { garden }\end{array}$ \\
\hline Parking & At-grade & Stacker & Basement \\
\hline Time in Planning & 10 months & 10 months & 10 months \\
\hline $\begin{array}{l}\text { Commercial/community } \\
\text { space }\end{array}$ & N/A & $\begin{array}{l}1 \text { small retail unit on } \\
\text { the ground floor }\end{array}$ & $\begin{array}{c}5 \text { retail units, } \\
\text { pedestrian access to } \\
\text { Sydney Road }\end{array}$ \\
\hline Build Standard & Medium & Medium & Medium \\
\hline Required rate of return & $20 \%$ & $20 \%$ & $20 \%$ \\
\hline Debt to Equity - \% Debt & $100 \%$ & $100 \%$ & $100 \%$ \\
\hline Interest Rate p.a & $12 \%$ & $12 \%$ & $12 \%$ \\
\hline $\begin{array}{l}\text { Average per sqm } \\
\text { Construction Costs }\end{array}$ & $\$ 1,646$ & $\$ 1,657$ & $\$ 1,622$ \\
\hline $\begin{array}{l}\text { Average per sqm } \\
\text { Apartment Sale Prices }\end{array}$ & $\$ 10,300$ & $\$ 8,800$ & $\$ 9,500$ \\
\hline \multicolumn{4}{|c|}{ Project financials for base case (Appendix Estate Master Summary Output) } \\
\hline Project IRR & $24.38 \%$ & $14.24 \%$ & $17.62 \%$ \\
\hline Net Development Profit & $\$ 997,218$ & $\$ 1,675,352$ & $\$ 10,954,239$ \\
\hline Development Margin & $28.82 \%$ & $14.57 \%$ & $24.08 \%$ \\
\hline Total Revenue $^{1}$ & $\$ 4,295,754$ & $\$ 12,695,134$ & $\$ 54,353,260$ \\
\hline Project Costs ${ }^{2}$ & $\$ 3,298,536$ & $\$ 11,019,782$ & $\$ 43,400,021$ \\
\hline - Construction Costs & $\$ 1,796,653$ & $\$ 7,204,237$ & $\$ 26,945,406$ \\
\hline - Land Purchase Costs & $\$ 957,000$ & $\$ 1,951,400$ & $\$ 8,118,000$ \\
\hline - Other Costs & $\$ 544,883$ & $\$ 1,864,145$ & $\$ 8,336,615$ \\
\hline Selling Costs & $\$ 161,612$ & $\$ 479,866$ & $\$ 2,091,195$ \\
\hline Total Development Costs & $\$ 3,460,148$ & $\$ 11,499,648$ & $\$ 45,491,216$ \\
\hline $\begin{array}{l}\% \text { Land Purchase of total } \\
\text { costs }\end{array}$ & $31 \%$ & $19 \%$ & $20 \%$ \\
\hline
\end{tabular}

${ }^{1}$ After GST

${ }^{2}$ After GST reclaimed 
Table 2. Scenario initiatives

\begin{tabular}{|c|c|c|c|}
\hline Initiative & Feasibility input affected & Revenue & Costs \\
\hline $\begin{array}{l}\text { Affordable } \\
\text { housing } \\
\text { contribution } \\
\text { (AHC) }\end{array}$ & $\begin{array}{l}\text { AHC requirements of } 5 \%, 10 \%, 15 \% 20 \%, 25 \% \\
\text { and } 30 \% \text { of the development. Sales revenue } \\
\text { reduced and cost reduction 5\%. Sold to an } \\
\text { affordable housing not-for-profit provider for } 25 \% \\
\text { less than the market purchase price. }\end{array}$ & & \\
\hline Land subsidy & $30 \%$ reduction in land costs & & \\
\hline Density bonus & $\begin{array}{l}\text { Increase in apartments } 20 \% \text {, gross realisation } \\
\text { increase, cost increases. }\end{array}$ & & \\
\hline $\begin{array}{l}\text { Low interest } \\
\text { finance }\end{array}$ & Interest rate from $12 \%$ to $7 \%$ (debt $100 \%$ ) & & \\
\hline $\begin{array}{l}\text { Car parking } \\
\text { reduction }\end{array}$ & $\begin{array}{l}\text { Reduced costs - } \$ 45,000 \text { per carpark, reduced } \\
\text { revenue for the car parks. The additional space } \\
\text { gained by not including a car park, was not } \\
\text { reutilised in the building of the apartments }\end{array}$ & & \\
\hline $\begin{array}{l}\text { Fast-track } \\
\text { planning }\end{array}$ & Reduced planning time by half. & & \\
\hline
\end{tabular}


Table 3. Scenario Analysis of the Percentage Change to Market Baseline in Profit and IRR.

\begin{tabular}{|c|c|c|c|c|c|c|c|c|c|c|c|}
\hline \multirow[b]{2}{*}{$\begin{array}{c}\text { Case } \\
\text { Project }\end{array}$} & \multirow[b]{2}{*}{ Initiative } & \multicolumn{2}{|c|}{$\begin{array}{c}10 \% \\
\text { Affordable } \\
\text { units }\end{array}$} & \multicolumn{2}{|c|}{$\begin{array}{c}15 \% \\
\text { Affordable } \\
\text { units }\end{array}$} & \multicolumn{2}{|c|}{$\begin{array}{c}20 \% \\
\text { Affordable } \\
\text { units } \\
\end{array}$} & \multicolumn{2}{|c|}{$\begin{array}{c}25 \% \\
\text { Affordable } \\
\text { units } \\
\end{array}$} & \multicolumn{2}{|c|}{$\begin{array}{c}30 \% \\
\text { Affordable } \\
\text { units } \\
\end{array}$} \\
\hline & & IRR & Profit & IRR & Profit & IRR & Profit & IRR & Profit & IRR & Profit \\
\hline \multirow[t]{5}{*}{ Micro } & $\begin{array}{c}\text { Density } \\
\text { Bonus 20\% }\end{array}$ & $+14 \%$ & $+24 \%$ & $+10 \%$ & $+19 \%$ & $+5 \%$ & $+13 \%$ & $+1 \%$ & $+7 \%$ & $-4 \%$ & $+1 \%$ \\
\hline & $\begin{array}{c}\text { Land } \\
\text { Subsidy } \mathbf{3 0 \%}\end{array}$ & $+41 \%$ & $+26 \%$ & $+37 \%$ & $+21 \%$ & $+32 \%$ & $+16 \%$ & $+28 \%$ & $+11 \%$ & $+24 \%$ & $+6 \%$ \\
\hline & $\begin{array}{c}\text { Low Finance } \\
7 \%\end{array}$ & $+10 \%$ & $+8 \%$ & $+6 \%$ & $+3 \%$ & $+2 \%$ & $-2 \%$ & $-2 \%$ & $-7 \%$ & $-6 \%$ & $-11 \%$ \\
\hline & $\begin{array}{c}\text { Fast Track - } \\
3 \text { months }\end{array}$ & $+62 \%$ & $+8 \%$ & $+56 \%$ & $+3 \%$ & $+50 \%$ & $-2 \%$ & $+44 \%$ & $-6 \%$ & $+37 \%$ & $-11 \%$ \\
\hline & $\begin{array}{c}\text { Remove } \\
\text { Car-parks }\end{array}$ & $-1 \%$ & $-4 \%$ & $-5 \%$ & $-9 \%$ & $-9 \%$ & $-13 \%$ & $-13 \%$ & $-18 \%$ & $-17 \%$ & $-23 \%$ \\
\hline \multirow[t]{5}{*}{ Small } & $\begin{array}{c}\text { Density } \\
\text { Bonus 20\% }\end{array}$ & $+51 \%$ & $+71 \%$ & $+43 \%$ & $+60 \%$ & $+36 \%$ & $+50 \%$ & $+28 \%$ & $+40 \%$ & $+20 \%$ & $+30 \%$ \\
\hline & $\begin{array}{c}\text { Land } \\
\text { Subsidy } \mathbf{3 0 \%}\end{array}$ & $+42 \%$ & $+28 \%$ & $+34 \%$ & $+20 \%$ & $+26 \%$ & $+12 \%$ & $+18 \%$ & $3 \%$ & $+10 \%$ & $-5 \%$ \\
\hline & $\begin{array}{c}\text { Low Finance } \\
\mathbf{7 \%}\end{array}$ & $+19 \%$ & $+17 \%$ & $+12 \%$ & $+8 \%$ & $+4 \%$ & $0 \%$ & $-3 \%$ & $-8 \%$ & $-11 \%$ & $-16 \%$ \\
\hline & $\begin{array}{c}\text { Fast Track - } \\
3 \text { months }\end{array}$ & $+28 \%$ & $+4 \%$ & $+19 \%$ & $-4 \%$ & $+10 \%$ & $-12 \%$ & $0 \%$ & $-20 \%$ & $-9 \%$ & $-29 \%$ \\
\hline & $\begin{array}{c}\text { Remove } \\
\text { Car-parks }\end{array}$ & $+3 \%$ & $-5 \%$ & $-4 \%$ & $-12 \%$ & $-12 \%$ & $-20 \%$ & $-19 \%$ & $-27 \%$ & $-27 \%$ & $-35 \%$ \\
\hline \multirow[t]{8}{*}{ Medium } & $\begin{array}{c}\text { Density } \\
\text { Bonus 20\% }\end{array}$ & $+28 \%$ & $+45 \%$ & $+23 \%$ & $+38 \%$ & $+18 \%$ & $+31 \%$ & $+13 \%$ & $+25 \%$ & $+8 \%$ & $18 \%$ \\
\hline & $\begin{array}{c}\text { Land } \\
\text { Subsidy } \mathbf{3 0 \%} \\
\end{array}$ & $+32 \%$ & $+19 \%$ & $+27 \%$ & $+13 \%$ & $+22 \%$ & $+8 \%$ & $+17 \%$ & $+2 \%$ & $+12 \%$ & $-3 \%$ \\
\hline & $\begin{array}{c}\text { Low Finance } \\
7 \%\end{array}$ & $+17 \%$ & $+15 \%$ & $+12 \%$ & $+9 \%$ & $+8 \%$ & $+4 \%$ & $+3 \%$ & $-2 \%$ & $-2 \%$ & $-7 \%$ \\
\hline & $\begin{array}{c}\text { Fast Track - } \\
3 \text { months }\end{array}$ & $+20 \%$ & $+1 \%$ & $+14 \%$ & $-4 \%$ & $9 \%$ & $-10 \%$ & $+3 \%$ & $-15 \%$ & $-3 \%$ & $-21 \%$ \\
\hline & $\begin{array}{c}\text { Remove } \\
\text { Car-parks }\end{array}$ & $+26 \%$ & $+17 \%$ & $+21 \%$ & $+12 \%$ & $+17 \%$ & $+7 \%$ & $+12 \%$ & $+2 \%$ & $+8 \%$ & $-3 \%$ \\
\hline & \multicolumn{11}{|c|}{$\begin{array}{l}\text { Viable - Both the IRR and Profit are greater than or equal to the Baseline figure, with a positive or } 0 \\
\text { percentage change }\end{array}$} \\
\hline & \multicolumn{11}{|c|}{$\begin{array}{l}\text { Possibly viable - One of the IRR and Profit are greater than or equal to the Baseline figure, with a } \\
\text { positive or } 0 \text { percentage change. }\end{array}$} \\
\hline & \multicolumn{11}{|c|}{$\begin{array}{l}\text { Not Viable }=\text { Both the IRR and Profit are less than the Baseline figure, with a negative percentage } \\
\text { change. }\end{array}$} \\
\hline
\end{tabular}




\section{Appendix: Estate Master Feasibility Results Summarised for Base Cases}

\begin{tabular}{|c|c|c|c|}
\hline & Micro & Small & Medium \\
\hline \multicolumn{4}{|l|}{ Gross Sales Revenue } \\
\hline Site Area & $133 \mathrm{sqm}$ & 509 sqm & $2,161 \mathrm{sqm}$ \\
\hline Gross Floor Area & 665 & 2,443 & 15,000 \\
\hline Project Size & 5 units & 26 units & 114 units \\
\hline Revenue from Apartment Sales & $\$ 4,903,103$ & $\$ 14,492,500$ & $\$ 62,090,000$ \\
\hline Less selling costs & $(\$ 161,612)$ & $(\$ 479,866)$ & $(\$ 2,091,195)$ \\
\hline NET SALES REVENUE & $\$ 4,741,491$ & $\$ 14,012,634$ & $\$ 59,998,805$ \\
\hline TOTAL REVENUE (before GST paid) & $\$ 4,741,491$ & $\$ 14,012,634$ & $\$ 59,998,805$ \\
\hline Less GST paid on all Revenue & $(\$ 445,737)$ & $(\$ 1,317,500)$ & $(\$ 5,644,545)$ \\
\hline TOTAL REVENUE (after GST paid) & $\$ 4,295,754$ & $\$ 12,695,134$ & $\$ 54,354,260$ \\
\hline \multicolumn{4}{|l|}{ Costs } \\
\hline Land Purchase Cost & $\$ 957,000$ & $\$ 1,951,400$ & $\$ 8,118,000$ \\
\hline Land Acquisition Costs & $\$ 62,060$ & $\$ 126,841$ & $\$ 527,670$ \\
\hline $\begin{array}{l}\text { Construction costs } \\
\text { (Residential, Commercial \& General) }\end{array}$ & $\$ 1,796,653$ & $\$ 7,204,237$ & $\$ 26,945,406$ \\
\hline Professional Fees & $\$ 149,472$ & $\$ 599,551$ & $\$ 2,238,281$ \\
\hline Statutory Fees & $\$ 6,292$ & $\$ 25,663$ & $\$ 68,340$ \\
\hline Project Contingency (Reserve) & $\$ 97,880$ & $\$ 390,603$ & $\$ 1,461,744$ \\
\hline Land Holding Costs & $\$ 25,000$ & $\$ 145,000$ & $\$ 340,000$ \\
\hline Pre-sale commissions & $\$ 46,864$ & $\$ 149,904$ & $\$ 604,419$ \\
\hline Finance Changes (inc Fees) & $\$ 45,213$ & $\$ 144,000$ & $\$ 588,000$ \\
\hline Interest Expense & $\$ 404,714$ & $\$ 1,263,837$ & $\$ 6,284,235$ \\
\hline TOTAL COSTS (before GST reclaimed) & $\$ 3,591,149$ & $\$ 12,001,036$ & $\$ 47,176,095$ \\
\hline Less GST reclaimed & $(\$ 292,613)$ & $(\$ 981,254)$ & $(\$ 3,776,073)$ \\
\hline TOTAL COSTS (after GST reclaimed) & $\$ 3,298,536$ & $\$ 11,019,782$ & $\$ 43,400,021$ \\
\hline \multicolumn{4}{|l|}{ Performance Indicators } \\
\hline Net Development Profit ${ }^{1}$ & $\$ 997,218$ & $\$ 1,675,352$ & $\$ 10,954,239$ \\
\hline Development Margin $^{2}$ & $28.82 \%$ & $14.57 \%$ & $24.08 \%$ \\
\hline Net Present Value (discount rate of $20 \%$ p.a.) ${ }^{3}$ & $\$ 121,419$ & $(\$ 434,267)$ & $\$ 46,483$ \\
\hline Benefit Cost Ratio $^{4}$ & 1.0506 & 0.9414 & 1.0016 \\
\hline Project Internal Rate of Return (IRR) ${ }^{5}$ & $24.38 \%$ & $14.24 \%$ & $\$ 7,419,146$ \\
\hline
\end{tabular}

(After: Estate Master 2019)

\footnotetext{
${ }^{1}$ Development profit: is total revenue less total cost including interest paid and received (Estate Master 2019)

${ }^{2}$ Development Margin: is profit divided by total costs (including selling costs) (Estate Master 2019)

${ }^{3}$ Net Present Value: is the project's cash flow stream discounted to present value. It includes all financing costs and interest but excludes corporate tax. (Estate Master 2019)

${ }^{4}$ Benefit cost ratio: is the ratio of discounted incomes to discounted costs and includes all financings and interest but excludes corporate tax. (Estate Master 2019)

${ }^{5}$ Internal rate of return: is the discount rate where the NPV above equals Zero, and per annum nominal. (Estate Master 2019)
} 